\title{
NUTRITIONAL AND ENVIRONMENTAL CONSIDERATIONS OF FOOD STOCKPILES IN JAPAN AND USA: REDUCING FOOD WASTE BY EFFICIENT REUSE THROUGH THE FOOD BANKS
}

\author{
M. SATO ${ }^{1}$, M. NAKANO ${ }^{1}$, K. GATTO ${ }^{2} \&$ S. WUNDERLICH ${ }^{2}$ \\ ${ }^{1}$ Keio University, Yokohama, Japan. \\ ${ }^{2}$ Montclair State University, Montclair, NJ USA.
}

\begin{abstract}
The food stockpiles of local self-governing bodies comprise the first urgent response to a disaster, but stockpiled food has a best-before date and will be wasted if not used. Therefore, it is necessary to devise a method for using (reusing) stockpiles efficiently. This study proposes cooperation between local self-governing bodies, food banks, and special food supermarkets in Japan and USA to improve the food quality and nutritional value of stockpiles and reduce food waste. Japan's food stockpile is estimated to be 40,015.5 tons, and though there is no exact information regarding America's stockpiles, there are estimated approximately 200 active food banks and 63,000 smaller food pantries. Analysis of Japan's stockpiled food revealed a high-energy ratio of lipids and carbohydrates along with insufficient amounts of vitamins and minerals. However, in foods supermarkets, huge amounts of vegetables and fruits are now being discarded which could provide the deficient nutrients. Through cooperation of food supermarkets and food banks, it may be possible to promote the efficient reuse of the stockpiles of local self-governing bodies and improve the nutritional value of stockpiles. During the research period, Japan had 40 food banks and reutilized 1,512 tons of food waste from these food banks each year, which is only $0.1 \%$ of the food waste discarded from the entire food industry in Japan. Subsidies provided in 2010 by the Ministry of Agriculture, Forestry, and Fisheries stimulated the activity of food banks, which work under the viewpoint of food waste reduction. The researchers investigated the profile of America's food banks compared to the food bank activity in Japan to stimulate food bank activity in both countries while considering the viewpoints of waste management, environmental impact and economics.
\end{abstract}

Keywords: food bank, food stockpiles, food waste, Reuse.

\section{INTRODUCTION}

Preparation of food stockpiles in the case of a disaster is progressing in Japan, but for much of the stockpiled food, there is a best-before date (Expiration date). If there is no disaster, stockpiled food will be wasted. Effort to stockpile water and food has been advanced in local governments. However, a food band (The Second Harvest Japan) has pointed out that many of these supplies have been wasted [1]. In addition, because of the emergency response, there have been no studies on stockpiling food from the food quality and nutritional point of view. Nutritional analysis is necessary. If a nutritional drawback is found, it will be necessary to propose a method for improvement. Therefore, in this study, the first objective is to clarify the actual conditions and nutritional assessment of food to stockpiles of the Japanese local government, which has been prepared using taxes (public money). Also, it is necessary to devise 
a good method for handling stockpiled food with a best-before date. Determining how to carry out the reuse without waste requires a plan for effective usage. The authors believe that cooperation with the food bank, which was first established in the US, while upholding the value of social welfare can lead to the effective utilization of municipal stockpile food and reduction of waste [2].

Recently, in Japan, due to the influence of subsidy of the Ministry of Agriculture, Forestry and Fisheries, a new movement has been developed to promote food bank activities [3]. The authors revealed the recent reality of increasing numbers of food banks operating in Japan [2]. The second objective is to correspondingly clarify the actual conditions of food banks for further development in Japan.

There is a need for people and food bank activities to take the advantage of the food bank before spoilage occurs [4-6]. Food supermarkets and food banks can play a cooperating role, but such relationships are not progressing. Therefore, in this study, cooperation with food supermarkets for nutritional improvement of stockpiling food is proposed. The cooperation of food supermarkets and food banks along with environmental and economic effects will be discussed.

\section{ESTIMATION OF THE TOTAL AMOUNT OF STOCKPILING FOOD IN LOCAL GOVERNMENT AND ITS NUTRITIONAL VALUE PER CAPITA}

The total amount of stockpiling food in local government in Japan was calculated and the nutritional value per capita of stockpiling food was assessed.

\subsection{Method of investigation}

2.1.1 Estimation of the amount of stockpiling food in local government The total weight of stockpiled food in 15 local government including Tokyo was calculated, and by dividing the weight of stockpile food by the total population of each of city, the stockpile food per capita was calculated. Then, the total amount was calculated by multiplying the food per capita by the total population of Japan.

\subsubsection{Nutritional value of the food to be stockpiled in local government}

The nutritional value of the stockpile food (hard tack crackers, bread, rice product, porridge, freeze-dried food, canned, survival foods, instant miso soup) were analyzed. First, the average amount of stockpile food for one serving was calculated. Using goods that are actually sold in one-serving increments, individual serving weight was used as a reference for calculation. In addition to the protein and energy ratio of lipids and carbohydrates, the nutritional assessment included analysis of minerals and vitamins. The standard nutrients were analyzed by comparison to the reference of Japan Dietary Reference Intakes 2010 [7]. Then, the content of minerals and vitamins for vegetables and fruits leading to the waste of food supermarkets was examined.

It was determined that the nutritional improvement in case of food in addition to stockpile food was necessary.

\subsection{Result}

\subsubsection{Estimation of the total amount stockpiling food in local government}

The total amount of stockpile food was calculated to be about 2,070 tons using the following formula. For calculation of the estimated amount, the following values were used. 
156 Environmental and Economic Impact on Sustainable Development

- $\quad Y$ :Stockpile estimated amount of Japan (g)

- $Q$ :Total amount of stockpile in Tokyo $(\mathrm{g})$

- $P$ :Total number of population in Tokyo

- $T:$ Total population in Japan

- $\mathrm{Y}=T^{*} Q / p$

2.2.2 Nutritional assessment of the stockpile food in the local government

Looking at the breakdown of the stockpile food, hardtack, biscuits, crackers, rice, and porridge were frequently included. Stockpiles of carbohydrate-based foods are plentiful. There is currently no issue with the short-term evacuation life, but the authors believe that nutritional stockpiles must be evaluated for their long-term shelf life. Therefore, the issue of waste was investigated. The protein-energy ratio for nutritional value of food $(\mathrm{P})$, the lipid energy ratio $(\mathrm{F})$, and carbohydrate energy ratio for $(\mathrm{C})$ for an average individual serving of food were calculated. Desired protein-energy ratio (P) is $3 \%-7 \%$ in one meal $(9 \%-20 \%$ in one day); desired lipid energy ratio $(\mathrm{F})$ is $7 \%-10 \%$ in one meal ( $20 \%-25 \%$ in one day); and desired carbohydrate energy ratio $(\mathrm{C})$ is $16 \%-30 \%$ for one meal $(50 \%-70 \%$ in one day). In actual average stockpile food, average protein-energy ratio $(\mathrm{P})$ is $8.8 \%$, lipid energy ratio $(\mathrm{F})$ is 24.5 carbohydrate energy ratio (C) is $66.7 \%$. When compared to the ideal distributions, carbohydrates and lipids are exceedingly high. In addition, critical vitamins and minerals are absent or low from the current food list. In terms of supply of vitamins and minerals, vegetables and fruits are critically important. Therefore, to effectively meet nutritional needs with stockpiled food, it is necessary to increase the presence of vegetables and fruits in stockpiles. Cooperation with food supermarkets can play a major role in securing available vegetables and fruits, which is important for long-term disaster recovery and at the same time reduce waste of perishable food. System construction that could tie food supermarkets to food bank activities are also important in view of the nutritional aspects of stockpile food.

\section{SURVEY OF FOOD BANKS IN JAPAN AND THE UNITED STATES}

We have already reported the recent reality of food banks operating in Japan, and the activity of food bank has been analyzed [2]. The actual situation in the US through the Internet research [8] was determined and analysis of the report published by Mitsubishi Research Institute [9].

\subsection{Survey method}

\subsubsection{Actual situation and activities of the food bank in the United States}

In the survey, 200 food banks were found to be currently active in the US according to the United States Department of Agriculture [8]. The philosophy behind each food bank establishment was examined to typify different organizations that can be considered food banks. Need-based relief types provide food to those in extreme need; food waste reduction types are intended to reduce food loss; the area of activity form is aimed at regional activities. The authors counted the number of organizations and applied this classification based on the Japanese researcher's original classification [2]. In addition, subsidies for food bank and laws related to food bank were also investigated.

\subsubsection{Japan-US comparison of food bank activities}

United States is a food bank birthplace, and food bank activities are now being developed elsewhere in the world, including Japan. Knowing the advanced example of United States is 
contributing to the activation of Japanese food bank activities. Therefore, we have carried out the Japan-US comparison of food bank activities: first, the United States food bank activities, the number of organizations, the purpose of the food bank activities, donations from individuals, donations from industry associations, corresponding administrative action (subsidies, legislation to exempt tax incentives, the responsibility of food providers in the event of an accident), and other features (funding from the food supply destination, the handling of the expired products) were surveyed. A comparison of the actual situation and the realities of US and Japanese food bank activities were then performed. The important matters that should be considered within food banks in Japan were clarified.

\subsection{Survey result}

\subsubsection{Classification of the activity of food banks in Japan}

Differences in the philosophy of each food bank in the United States led to classification into the following categories: relief, reduction, regional activated, and other. Although the relieftype category is large, many food banks are geared toward reducing food waste and consequently reducing negative impact on the environment.

Relief-type food banks, which share the primary purpose of providing assistance to the needy, include soup kitchens and food distribution to street dwellers. Reduction type food banks exist to salvage food waste, often gathered from non-standard farmers. In the region active form of food banks, activities are carried out by sales of restaurant in the region.

Japan's food bank organization, which was founded upon the principles of food waste reduction, experienced growth after 2010 when the Ministry of Agriculture, Forestry and Fisheries established subsidies to support food banks [2]. Food banks rely on support of the government as well as industry; manufacturers, retailers, farmers and power companies, local governments, and religious facilities have all been listed as donors [2].

Total annual handling capacity of major food bank of Japan is 1,512 tons [10]. This amount is less than $0.1 \%$ of the amount of waste that is discharged from the entire food industry (about 19.16 million tons) [10].

There is also a food bank involved in the acceptance and provision of municipal stockpile food. Although local government is promoting disaster food stockpiles, the best-before expiration date issue has become a challenge. Use of food banks has been suggested as a possible solution. Taken together, these food bank activities are determined as 1-4.

1. When viewed from the activities philosophy, there are many food banks working under the point of view of social and food waste reduction.

2. In Japan, subsidies of the Ministry of Agriculture, Forestry and Fisheries cab effectively activate food bank activities.

3. In Japan, 1/3 rule, such as expiration date setting limits the effective use of food. This rule is not law. From production date to the limited date of deliver is $1 / 3$, and from deliver date to the store to limited date of sale is $1 / 3$ and from sale to limited date of consumption in consumer is $1 / 3$.

By clarifying the background of the $1 / 3$ rule, it is presumed to lead to effective utilization of food.

4. Some of Japan's food banks are also organizations taken off the stockpile food of local government. 
158 Environmental and Economic Impact on Sustainable Development

3.2.2. Japan-US comparison of food bank activities and the points for Japanese food banks to learn the activity in the United States

Currently, there are 40 food banks in Japan and 200 or more in the United States [8]. There is a large population difference between the two, and in the United States, the Department of Agriculture is supporting the food bank activities by purchasing agricultural products from producers though there is no such system in Japan [2]. Also, in the event of an accident, funding from the system and the private sector are exempted from the responsibility of food providers in the United States. In addition, the food that for example biscuits such as long expiration date, ask to the manufacturer the limited of real limited date and give the food to people who need the food. Activities of food banks were initiated in the US in 1976 but were only established in Japan in 2000. The activity of food banks is developing in the United States compared to Japan. The food bank receives food from food supermarkets and manufacturing industry before being distributed to people and welfare facilities that require food, and this distribution supports lives and reduce waste. In the United States, provision of food to the poor is not considered an adequate solution to poverty problems; efforts are also made to teach cooking technology to poor individual, and programs support social reintegration of the poor. About $70 \%$ of the people who have received education also felt that they received social reintegration, which indicates success as a social welfare project in the United States. It should be noted that the food bank activity efforts are spreading across the world beyond the United States and Japan [9], Table 1.

On the other hand, food handling in the Japanese food bank is difficult due to the expiration dates of canned food, retort food, beverages, and fresh products (mainly vegetables and fruits). Operating costs are mainly donations from individuals and the private sector. Because ensuring food and donations is a difficult task, this has become a limiting factor in the spread of the food bank activities. To enhance the food bank activities in Japan, it is necessary to stimulate the idea of reducing type and regional active form food banks in favor of a combination of food waste reduction type and regional active form. The reason is that activities targeted toward the purpose of reducing food waste can easily receive a subsidy from the Ministry of Agriculture, Forestry and Fisheries. In addition, regional active form banks can provide assistance to people who are in trouble in the region and can be completed in the community. From the above, in Japan, there is a need for incorporating the principles of both reduction type and the regional active type activities. As further described in the Japan-US comparison of food bank activities, a system which would exempt the responsibility of food providers at the time of any in Japan is underdeveloped. In order to promote cooperation between food markets and food banks, in addition to advancing the role of adequate scientific knowledge, it is necessary to develop the liability of food providers.

\subsubsection{Problem on nutrition and food quality}

Some of Japan's homeless population has reported that intake of iron, vitamin A, B1, C, and dietary fibers were below recommended amount [11]. Lack of intake of vitamins and minerals has also been noted as an issue in other countries [12-14]. In order to improve the nutritional status of the homeless population, sufficient amounts of vegetables and fruits must be provided.

\section{THE WASTE OF FOOD SUPERMARKET}

There is a large amount of food waste in the supermarkets. It is recommended that employee education and food labeling help food waste reduction $[15,16]$. Food supermarket waste is 
Table 1: The points for Japanese food banks to learn from the food banks of United States of America.

\begin{tabular}{|c|c|c|c|}
\hline \multicolumn{2}{|l|}{$\square$} & America* & Japan \\
\hline \multicolumn{2}{|c|}{ Number of food banks } & more than 200 & 40 \\
\hline \multicolumn{2}{|c|}{ Purpose of food bank activity } & $\begin{array}{l}\text { The reduction in food loss } \\
\text { had been intended but the re- } \\
\text { lief of starvation has become } \\
\text { the main objective. }\end{array}$ & $\begin{array}{l}\text { Food waste reduction type, } \\
\text { life difficult } \\
\text { person of relief type, region } \\
\text { active }\end{array}$ \\
\hline \multicolumn{2}{|l|}{ Activity contents } & $\begin{array}{l}\text { Food donations as well, and } \\
\text { it is also carried out educa- } \\
\text { tion and training for social } \\
\text { reintegration }\end{array}$ & $\begin{array}{l}\text { Food manufacturers will be } \\
\text { asked to donate and it give } \\
\text { to welfare facilities. }\end{array}$ \\
\hline \multicolumn{2}{|c|}{ Benefits from individuals } & Acceptable & Acceptable \\
\hline \multicolumn{2}{|c|}{ Benefits from companies } & Acceptable & Acceptable \\
\hline \multirow[t]{3}{*}{$\begin{array}{l}\text { Corresponding } \\
\text { administrative }\end{array}$} & Subsidy & $\begin{array}{ll}\text { - } & \text { Subsidy system } \\
\text { - } & \text { USDA buy from pro- } \\
\text { ducers } \\
\text { - } & \text { Provision of agricul- } \\
& \text { tural } \\
\text { - } & \text { products to food banks }\end{array}$ & $\begin{array}{l}\text { No continuous subsidies } \\
\text { from the government }\end{array}$ \\
\hline & Tax incentives & Acceptable & None \\
\hline & $\begin{array}{l}\text { Law to be exempt from } \\
\text { the responsibility of } \\
\text { food providers in the } \\
\text { event of an accident }\end{array}$ & $\begin{array}{l}\text { Under the "Bill Emerson } \\
\text { Good Samaritan Food } \\
\text { Donation Act". }\end{array}$ & None \\
\hline \multirow[t]{2}{*}{ Other } & $\begin{array}{l}\text { The presence or absence } \\
\text { from the preceding that } \\
\text { provide food cost } \\
\text { procurement }\end{array}$ & The system is available & None \\
\hline & $\begin{array}{l}\text { Handling of relish } \\
\text { expired goods }\end{array}$ & $\begin{array}{l}\text { Biscuits with long expira- } \\
\text { tion date is offering after } \\
\text { checking the real deadline by } \\
\text { asking to the manufacture. }\end{array}$ & None \\
\hline
\end{tabular}

*For the actual situation in the United States. It is summarized based on the data described in the "2009 Food Bank Survey Report".

high, with vegetable and fruit waste accounting for as much as $65 \%$ [15]. Emphasizing the utilization of these foods in food banks before spoilage is crucial for environmental application. As the world population expands, the possibility of a food crisis would require extremely high volumes of food and would place a high level of stress on the environmental system. Currently, food is discarded from food stores when it could potentially be dedicated to stockpiles and distributed to those in need. Utilization of food, before discarding it as waste, can minimize the need for higher food supply and the strain that demand would place upon farmers, fields, and production methods. 
160 Environmental and Economic Impact on Sustainable Development

\section{COOPERATION OF LOCAL GOVERNMENT WITH FOOD BANK AND FOOD SUPERMARKET}

\subsection{Nutritional improvement of the food bank food}

Nutritional value was analyzed for $100 \mathrm{~g}$ each of lettuce, cabbage, tomato, grapefruit, banana, and strawberry, as this amount is typically the amount in one meal. In addition, we calculated the nutrition component value of total $600 \mathrm{~g}$ (lettuce, cabbage, tomato, grapefruit, banana, and strawberry,) when it was added to each $100 \mathrm{~g}$ average stockpile food (1 serving). The results indicate that for minerals, sodium, potassium, iron, zinc (man), there are more than the estimated average amount required for copper and manganese (woman). For vitamins, vitamin E, K, B1, B2 (woman), B6, VC and the value of folic acid and niacin (woman) were higher than the estimated average necessary amounts. Vitamins A, D, and B12 are not contained minimally or not at all in the vegetables and fruits, so they may need to be supplemented. By adding the vegetables and fruits to stockpile food before being wasted at the food supermarket, it can supply more than the estimated average necessary amount for many nutrients.

5.2 Estimation of the amount of waste reduction in local government and food supermarket

According to the 2012 survey report of Ministry of Health, Labor and Welfare in Japan, the total number of Japan's homeless is 9,576 people [17]. In the nutrition survey of homeless people in a region in Japan, iron, vitamin A, B1, C, and dietary fiber were insufficient [11]. It is estimated that local governments in Japan stockpile approximately 2,070 tons of food (Table 2). When stockpiled food includes vegetables and fruits, this can also leads to improved nutrition for homeless people. If we have an average of stockpiling of $70.2 \mathrm{~g}$ foods per meal, the estimated stockpile food at this time, it will be about 29,486,205 servings, which can supply approximately 2.8 years of three servings per day for 9,576 people homeless. In addition, this approximately 29,486,205 servings of stockpiled food combined with the matched vegetables and fruits, when calculated as one meal $600 \mathrm{~g}$, becomes about 17,691.72 tons as of 2012, as food waste from food supermarkets is about 1.22 million tons [18], 65\% of the total waste from supermarkets is the waste of vegetable and fruits. Therefore, the waste of vegetable and fruits is 0.793 million tons from food supermarkets alone [15]. If vegetable and fruit are completely used for nutritional improvement of the stockpiled food, $2.23 \%$ of food waste derived from in the supermarket will decrease. This minimization of food loss is environmentally necessary, as utilization of all edible food should be prioritized to minimize stress on the world's resources. Salvaging food from supermarkets can help deliver the world's abundance to those in need of nourishment and therefore lower the strain on global food supply.

The total amount of food handled in 1-year for all 40 food bank organizations in Japan is 1,512 tons [10], which illustrates the magnitude of Japan's stockpile food amount. In cooperation with the food banks, if food can be effectively reused, efforts can be made to greatly advance both global food security and social welfare and reduce negative environmental impact. The nutritional values of stockpiling provide minimal food options; carbohydrates and lipids are high while vitamins and minerals are low or missing. For the nutritional improvement, the coordination of food supermarkets and a food bank dedicated to handling vegetables and fruits are important. If collaboration is established, it is possible to improve the nutritional value of stockpiling food, and food bank efforts can advance significantly. On the other hand, also it enables food assistance based on nutritional assessment in the case of 
Table 2: Environmental and economic evaluation of the cooperation of the food stockpiles in local government with the food banks and food supermarket in Japan.

\begin{tabular}{|c|c|c|}
\hline This points discussed in this paper & Value & Environment and economic effects \\
\hline $\begin{array}{l}\text { Estimated total amount of stockpile } \\
\text { food in local governments }\end{array}$ & 2,070 tons & $\begin{array}{l}29,486,205 \text { meals for } 70.2 \mathrm{~g} \text { per } \\
\text { one meal }\end{array}$ \\
\hline $\begin{array}{l}\text { Estimated total amount of vegetable } \\
\text { and fruits necessary for improving } \\
\text { nutritional value of stockpile food }\end{array}$ & $\begin{array}{l}17,691.72 \\
\text { tons }\end{array}$ & $\begin{array}{l}2.23 \% \text { reduction of the food waste } \\
\text { of vegetable and fruits in food } \\
\text { supermarket } \\
\text { when used for improvement of } \\
\text { stockpile food in local govern- } \\
\text { ment }\end{array}$ \\
\hline $\begin{array}{l}\text { Total amount of food waste from } \\
\text { entire food industry }\end{array}$ & $\begin{array}{l}19,160,000 \\
\text { tons }\end{array}$ & $\begin{array}{l}\text { Environmental and economic loss } \\
\text { is large. Burial and incineration } \\
\text { are necessary at present. }\end{array}$ \\
\hline $\begin{array}{l}\text { Total amount of food that food banks } \\
\text { deal with per year }\end{array}$ & 1,512 tons & $\begin{array}{l}\text { When the food banks deal with } \\
\text { food waste from stockpile food } \\
\text { in local government and entire } \\
\text { food industry. The activity of } \\
\text { food banks will be enhanced. The } \\
\text { reduction of the waste in super- } \\
\text { market and entire food industry } \\
\text { will be also performed }\end{array}$ \\
\hline $\begin{array}{l}\text { Total number of homeless people } \\
2012 \text { in Japan }\end{array}$ & 9,576 persons & $\begin{array}{l}\text { Food support and nutritional im- } \\
\text { provement are necessary }\end{array}$ \\
\hline
\end{tabular}

unexpectedly long-term support. Moreover, even in the grocery supermarkets, the result of collaboration may be a reduction of the discarded vegetables and fruits rich in minerals and vitamins. The salvaging of food and optimal reuse can result in significant benefits to the environment and may possibly help economic issue in Japan.

\section{ACKNOWLEDGMENTS}

In carrying out this study, we obtained kind support from the Japanese Food Bank organizations, in particular the Second Harvestin Japan, Aiai Ainetto Hiroshima, Food Bank Fukuyama, Food Bank Shimane, Fu-Dobanku northeast Again, Food Bank Kansai, NPO Corporation Mimatsu Association, and Food Bank Toyama. Thank you very much for collaborating with us on this project, and we hope to continue this collaboration in the future.

\section{REFERENCES}

[1] Ide, R., Current situation and challenges related to the Food Recycling Law, a proposal, In the Meeting document, 4th meeting of Food Recycling Sumcmitlee in the Council of Food, Agriculture and Rural Policy, Ministry of Agriculture, Forestry and Fisheries, 2013, (in Japanese without English summary).

[2] Sato, M. \& Nakano, M., Activity of the food bank in Japan and problems based on the viewpoint of Shokuiku Education. Journal of Japanese Education Society, 10(1), pp. 31-40, 2016. 
162 Environmental and Economic Impact on Sustainable Development

[3] Stockpile in Osaka, Osaka City website, available at http://www.city.osaka.lg.jp/kikikanrishitsu/page/0000011847.html

[4] Rush, T.J., Ng, V., Inwin, J.D., Stitt, L.W. \& He, M., Food insecurity and dietary intake of immigrant food bank users. Canadian Journal of Dietetic Practice and Research, 68(2), pp. 73-78, 2007. http://dx.doi.org/10.3148/68.2.2007.73

[5] Warshawsky, D.N., New power relations served here: the growth of food banking in Chicago. Geforum, 41, pp. 763-775, 2010. http://dx.doi.org/10.1016/j.geoforum.2010.04.008

[6] Tarasuk, V. \& Eakin, J.M., Charitable food assistance as symbolic gesture: an ethnographic study of food banks in Ontario. Social Science \& Medicine, 56, pp. 1505$1515,2003$. http://dx.doi.org/10.1016/S0277-9536(02)00152-1

[7] Ministry of Health., Labour and Welfare, Dietary Reference Intakes for Japanese 2010, 2009.

[8] Faith-Based and Neighborhood Partnerships, United States Department of Agriculture website, available at http://www.usda.gov/wps/portal/usda/usdahome?contentidonly=tr ue\&contentid=fnp_page $01-4 C . x m l$

[9] Mitsubishi Research Institute, 2009 food bank activities survey report, 2010 (In Japanese without English summary).

[10] Food Bank, Ministry of Agriculture, Forestry and Fisheries website, available at http:// www.maff.go.jp/j/shokusan/recycle/syoku_loss/foodbank/

[11] Tahara, E., Tabuchi, T., Haribara, S., Bando, T. \& Ido, T., The nutritional characteristics in homeless Osaka irine region. Nutrition Journal, 69(1), pp. 29-38, 2011.

[12] Sprake, E.F., Russelt, J.M. \& Barker, M.E., Food choice and nutrient intake amongst homeless people. Journal of Human Nutrition and Dietetics, 27, pp. 242-250, 2014. http://dx.doi.org/10.1111/jhn.12130

[13] Malmauret, L., Leblanc, J.Ch., Cuvelier, I. \&Veger, Ph., Dietary intake and vitamin status of a sample of homeless people in Paris. European Journal of Clinical Nutrition, 56, pp. 313-320, 2002. http://dx.doi.org/10.1038/sj.ejcn.1601312

[14] Tse, C. \& Tarasuk, V., Nutritional assessment of charitable meal programmes serving homeless people in Toronto. Public Heath Nutrition, 11(12), pp. 1296-1305, 2008. http://dx.doi.org/10.1017/S1368980008002577

[15] Sato, M. \& Nakano., M., Analysis of food waste in supermarket store and research for employee an attitude survey for reducing food waste. Journal of Japanese Society of Shokuiku, 7(4), pp. 259-283, 2013. http://dx.doi.org/10.2740/jisdh.23.166

[16] Sato, M. \& Nakano, M., The display on food product influencing the reduction of the amount of food waste. Journal for the Integrated Study of Dietary Habits, 23(3), pp. 166-173, 2012.

[17] Ministry of Health, Labour and Welfare, National Survey Committee on homeless realities 2012 report, 2013.

[18] Ministry of Agriculture, Forestry and Fisheries website, 2012 fiscal year food waste and recycling, 2013. 